\title{
Still present after all these years: persistence plus potential toxicity raise questions about the use of atrazine
}

\author{
Nicolai David Jablonowski • Andreas Schäffer • \\ Peter Burauel
}

Received: 12 August 2010 / Accepted: 7 December 2010 /Published online: 30 December 2010

(C) The Author(s) 2010. This article is published with open access at Springerlink.com

\begin{abstract}
As one of the worlds' most heavily applied herbicides, atrazine is still a matter of controversy. Since it is regularly found in ground and drinking water, as well as in sea water and the ice of remote areas, it has become the subject of continuous concern due to its potential endocrine and carcinogenic activity. Current findings prove long-held suspicions that this compound persists for decades in soil. Due to the high amount applied annually all over the world, the soil burden of this compound is considered to be tremendous, representing a potential long-term threat to the environment. The persistence of chemicals such as atrazine has long been underestimated: Do we need to reconsider the environmental risk?
\end{abstract}

Keywords Atrazine - Persistence · Half-life · Residues · Soil $\cdot$ Environmental risk

Responsible editor: Markus Hecker

Electronic supplementary material The online version of this article (doi:10.1007/s11356-010-0431-y) contains supplementary material, which is available to authorized users.

\footnotetext{
N. D. Jablonowski $(\bowtie) \cdot$ P. Burauel

Forschungszentrum Jülich $\mathrm{GmbH}$, Institute of Chemistry and Dynamics of the Geosphere,

ICG-4, Agrosphere,

52425 Jülich, Germany

e-mail: n.d.jablonowski@fz-juelich.de

N. D. Jablonowski

e-mail: n.d.jablonowski@daad-alumni.de

\section{A. Schäffer}

Institute for Environmental Research (Biology V),

RWTH Aachen University,

52074 Aachen, Germany

Since its introduction in the late 1950s the pre-emergent herbicide atrazine (6-chloro-N2-ethyl-N4-isopropyl-1,3,5triazine-2,4-diamine) has been among the most heavily used pesticides in the world. In the US, it has been ranked at or near the top, with up to 36,000 tons, applied annually since 1990, mainly for corn production (USEPA 2006). Atrazine is also used in Canada, Africa, and the AsiaPacific region (Huang et al. 2003; Kegley et al. 2010). In Europe, atrazine was used until the early 1990s when it was banned or severely restricted in most EU countries because drinking water concentrations exceeded or were estimated to exceed permitted limits. In 2004, the application of atrazine was finally banned in the European Union (E.U. 2004). Atrazine and its metabolites are well dispersed in the environment and persistent.

Atrazine use has resulted in widespread contamination of ground and surface waters and dispersal in the atmosphere. Atrazine is one of the most frequently detected pesticides in freshwater sources in the US (USEPA 1990; Benotti et al. 2009; Gilliom et al. 2006). Atrazine has been detected in rainwater frequently and in different places (Brun et al. 2008; Goolsby et al. 1997; Bossi et al. 2002; Sanusi et al. 2000), and also in fog, ambient air, arctic ice, and seawater - all at great distances from urban and agricultural areas (Glotfelty et al. 1987; Chernyak et al. 1996). Additionally, recent evidence of endocrine disruption (ED) activity of atrazine itself at environmentally relevant concentrations is cause for serious concern. In terms of a precautionary approach, we believe that the further use of atrazine should be halted or greatly curtailed.

Atrazine and its metabolites can persist in water and soil for decades. Even more than 18 years after it was banned in Germany, atrazine remains the most abundant pesticide in groundwater samples (LAWA 2003). The results of an atrazine long-term aging and a bioaccessibility study 
(Jablonowski et al. 2009; Jablonowski et al. 2010) underscore the high persistence of atrazine and its metabolites in soil. In 1983, a mixture of atrazine and atrazine ${ }^{14} \mathrm{C}$ labeled in the triazine ring was applied to a lysimeter in a corn field over three successive years at an application rate that was customary at the time (approximately $1.7 \mathrm{~kg}$ of active ingredient per hectare), without any further atrazine applications thereafter; 22 years later, $25 \%$ of the total applied ${ }^{14} \mathrm{C}$ activity was still present in the entire lysimeter soil. The major residual fraction of the applied ${ }^{14} \mathrm{C}$ activity was located in the upper $10 \mathrm{~cm}$ of the lysimeter soil, accounted for $9 \%$ of the initially total applied ${ }^{14} \mathrm{C}$ activity (Jablonowski et al. 2008b). In this 10-cm layer, the residual ${ }^{14} \mathrm{C}$ activity accounts for $0.5 \mathrm{~kg}$ atrazine equivalents, and we were able to extract with water-methanol solution $1.5 \mathrm{~g}$ atrazine, $75 \mathrm{~g}$ 2-hydroxy-atrazine (the initial hydrolysis product and microbial metabolite), extrapolated per hectare (Jablonowski et al. 2009). We assume that a considerable amount of the ${ }^{14} \mathrm{C}$ activity in the unidentified residue can be attributed to compounds with the triazine ring intact, since atrazine and 2-hydroxy-atrazine were extractable with weak solvents, and since cleavage of the triazine ring results in rapid mineralization. In our recent study, we found atrazine in an agriculturally used soil extractable in much higher amounts (approximately $19.5 \mathrm{~g}$ atrazine, calculated per hectare) 20 years after the last field application, as well as a number of atrazine metabolites in agricultural soils without documented atrazine application history (Jablonowski et al. 2010). Already Capriel et al. found that $83 \%$ of initially applied ${ }^{14} \mathrm{C}$-atrazine activity remained in the soil after an aging period of 9 years (Capriel et al. 1985). Both of these aging experiments involved limited applications of the herbicide; however, when applied annually over many years as in normal agricultural use, the accumulated amount of residues in soil is calculated to be substantial, even though the quantity of applied active ingredient in normal agricultural use was reduced to approximately $0.5 \mathrm{~kg}$ per hectare within the last years. The high persistence of atrazine ring carbon is not completely understood and could be due to a combination of binding to the soil matrix in unavailable forms or lack of metabolic capability. The accumulation of the parent compound in soil may represent a long-term source of dissolved or colloid-bound atrazine and its metabolites to ground water or surface waters. It is well-known that repeated application of atrazine leads to accelerated degradation due to the emergence of microbial populations that can use it as a source of nitrogen and carbon (Krutz et al. 2010; Martinazzo et al. 2010). However, our current studies suggest that even in soils showing an enhanced degradation of atrazine, a certain fraction of atrazine and its metabolites remains non-degraded but extractable (Jablonowski et al. 2010).
That, after decades of weathering, atrazine is still detectable, and metabolites (apparently with triazine ring intact) are still abundant in soil, underscores the need to assess the environmental behavior of this herbicide on longer time scales. A dissipation "half-life" (DT50), based on short-term laboratory experiments, is frequently used to characterize pollutant persistence despite questions about the concept. The lysimeter study clearly demonstrates the invalidity of applying a DT50 value obtained from shortterm experiments to long time scales; after 22 years we found a 550-fold greater concentration of atrazine than predicted by a DT50 of 1 year (Jablonowski et al. 2009) the longest among several reported values based on shortterm experiments (Jones et al. 1982). Whether such residues in place represent a risk remains an area of active debate. Periodic rainfall or irrigation may result in pulse inputs to underground or surface drinking water sources (Pignatello et al. 1993).

Exposure to atrazine may represent a potential threat to human and ecosystem health. Potentially the most serious threat is ED (Solomon et al. 2008; Rohr and McCoy 2010). The maximum allowable contaminant level for atrazine in drinking water is $0.1 \mu \mathrm{g} \mathrm{L}^{-1}$ (European Union), which was set as a precautionary value without toxicological effects for humans, $2 \mu \mathrm{g} \mathrm{L}^{-1}$ (World Health Organization) or $3 \mu \mathrm{g} \mathrm{L}^{-1}$ (United States Environmental Protection Agency USEPA), but at doses as low as $0.1 \mu \mathrm{g} \mathrm{L}^{-1}$, atrazine was found to cause dramatic changes in sexual differentiation in amphibians indicating a potential role in global amphibian decline (Hayes et al. 2002a, b; 2010; Tavera-Mendoza et al. 2002). Other studies, however, have found no ED in amphibians or mammals (Jooste et al. 2005; Trentacoste et al. 2001; Solomon et al. 2008; Spolyarich et al. 2010; Kloas et al. 2009). Most contradicting studies addressing the ED effects were conducted using the African clawed frog Xenopus laevis. To address the ED uncertainties regarding this test organism, a large set of experiments were conducted under guidance of the USEPA, coming to the conclusion that exposure to atrazine does not affect growth, larval development, or sexual differentiation (Kloas et al. 2009). In how far the scientific findings regarding ED effects in the test organism $X$. laevis can be extended to native frog species has been questioned previously (Renner 2008). However, a recently published meta-analysis of the existing literature "reveals consistent effects of atrazine on freshwater fish and amphibians," leading to the conclusion that the adverse "effects of atrazine must be weighed against any of its benefits" (Rohr and McCoy 2010). Reports appearing roughly the same time and not included in that review substantiate the claim for adverse reproductive effects of atrazine on fish (Tillitt et al. 2010) and amphibians (Langlois et al. 2010) at environmentally relevant concentrations in water (on the order of $1 \mu \mathrm{g} \mathrm{L}^{-1}$ ). Still, others show 
adverse developmental effects on amphibians (Lenkowski and McLaughlin 2010; Olivier and Moon 2010) or adverse reproductive effects on rats (Abarikwu et al. 2010) at more elevated concentrations. It appears that the issue is not completely resolved at this time.

Given the widespread dispersal and persistence of atrazine and its metabolites in the environment, the claim of ED effects among amphibians and mammals, if valid, is cause for alarm. A USEPA decision document for atrazine issued in 2006 and a white paper in support of this "Interim Reregistration Eligibility Decision on Atrazine" (Steeger et al. 2007; USEPA 2006) seemed to give it a clean bill of health, and, citing the contradicting studies, referred to the ED potential as being merely "hypothetical at this time." Since the 2006 review, however, a USEPA scientific advisory panel has decided to re-evaluate the potential health effects of atrazine on humans because of epidemiological data meeting the agency's criteria suggesting an association between atrazine and delayed menopause, increased gestational diabetes or reduced semen quality (Erickson 2010).While these studies cannot be used in quantitative risk assessment according to the agency because they lack exposure-response and individual exposure measurements, they are nevertheless consistent in many ways with animal toxicological studies and USEPA is taking them seriously.

Regardless of whether or not atrazine is found safe for humans, the demonstration of ED effects in wildlife at environmentally relevant concentrations is justification for a re-evaluation of the continued broad-scale use of atrazine. One's first reaction is to decry the paucity of data and lack of understanding of the fate and effects of atrazine. Obviously, a priority should be to resolve the ED controversy surrounding atrazine. Studies with this goal in mind should be conducted by independent parties without a stake in the outcome, include all relevant test organisms, take into account the differing reproductive cycles of individual organisms, and be performed at field-relevant dose regimes. Unfortunately, official standards for evaluating ED potential of anthropogenic chemicals in general do not yet exist, no doubt encumbered by the experimental challenges inherent in ED. Long-term effects on wildlife, particularly aquatic organisms, are difficult to simulate in the laboratory, both as a result of potential time limitations due to organisms' seasonal reproductive cycles and the complex interactions and food chain dependencies that affect the system-wide movement of pollutants in the environment. Effects on humans remain a possibility but are even more difficult to evaluate. While atrazine metabolites are typically less acutely toxic than atrazine itself, little is known about their ED effects (Tran et al. 1996) while many of them are more persistent than atrazine and remain water extractable even after long-term aging
(Jablonowski et al. 2008a). To date, data on the ecological impact of the various atrazine metabolites in environmentally relevant concentrations sparsely exist. Due to the fact that many of them are widely dispersed in waters and have been found in greater concentrations than the parent compound atrazine (Loos et al. 2010; Lerch et al. 1998), atrazine metabolites should be considered more in testing protocols.

All available information clearly suggests that it will take decades for atrazine and the accumulated metabolites to be degraded in the environment. In the meantime, ongoing surveillance of atrazine and its metabolites in ground/surface waters and soils is essential, not only in areas of direct application but also in remote areas. Further research on the environmental behavior of atrazine and its degradation products should be supported. Since soil is a long-term sink for many chemical pollutants, the data obtained for atrazine are likely to have broad relevance. A concerted effort is needed to obtain more conclusive data on the ED effects of atrazine and its metabolites on amphibians and mammals, and humans, to finally reconsider the wide use of atrazine.

Open Access This article is distributed under the terms of the Creative Commons Attribution Noncommercial License which permits any noncommercial use, distribution, and reproduction in any medium, provided the original author(s) and source are credited.

\section{References}

Abarikwu SO, Adesiyan AC, Oyeloja TO, Oyeyemi MO, Farombi EO (2010) Changes in sperm characteristics and induction of oxidative stress in the testis and epididymis of experimental rats by a herbicide, atrazine. Arch Environ Contam Toxicol 58 (3):874-882. doi:10.1007/s00244-009-9371-2

Benotti MJ, Trenholm RA, Vanderford BJ, Holady JC, Stanford BD, Snyder SA (2009) Pharmaceuticals and endocrine disrupting compounds in US drinking water. Environ Sci Technol 43(3):597-603

Bossi R, Vejrup KV, Mogensen BB, Asman WAH (2002) Analysis of polar pesticides in rainwater in Danmark by liquid chromatographytandem mass spectrometry. J Chromatogr A 957:27-36

Brun GL, MacDonald RM, Verge J, Aubé J (2008) Long-term atmospheric deposition of current-use and banned pesticides in Atlantic Canada; 1980-2000. Chemosphere 71:314-327

Capriel P, Haisch A, Khan SU (1985) Distribution and nature of bound (nonextractable) residues of atrazine in a mineral soil nine years after the herbicide application. J Agric Food Chem 33:567569

Chernyak SM, Rice CP, McConnell LL (1996) Evidence of currentlyused pesticides in air, ice, fog, seawater and surface microlayer in the Bering Sea and Chukchi Seas. Mar Pollut Bull 32:410-419

E.U. (2004) E.U. Commission Decision of 10 March 2004. Official Journal of the European Union

Erickson BE (2010) Atrazine debate intensifies. Chem Eng News 88 (41):31-33. doi:10.1021/CEN100510114940

Gilliom RJ, Barbash JE, Crawford CG, Hamilton PA, Martin JD, Nakagaki N, Nowell LH, Scott JC, Stackelberg PE, Thelin GP, 
Wolock DM (2006) Pesticides in the nation's streams and ground water, 1992-2001: U.S. Geological Survey Circular 1291. USGS

Glotfelty DE, Seiber JN, Liljedahl LA (1987) Pesticides in fog. Nature 325:602-605

Goolsby DA, Thurman EM, Pomes ML, Meyer MT, Battaglin WA (1997) Herbicides and their metabolites in rainfall: origin, transport, and deposition patterns across the Midwestern and Northeastern United States, 1990-1991. Environ Sci Technol $31: 1325-1333$

Hayes TB, Collins A, Lee M, Mendoza M, Noriega N, Stuart A, Vonk A (2002a) Hermaphroditic, demasculinized frogs after exposure to the herbicide atrazine at low ecologically relevant doses. Proc Natl Acad Sci 99:5476-5480

Hayes TB, Haston K, Tsui M, Hoang A, Haeffele C, Vonk A (2002b) Feminization of male frogs in the wild. Nature 419:895-896

Hayes TB, Khoury V, Narayan A, Nazir M, Park A, Brown T, Adame L, Chan E, Buchholz D, Stueve T, Gallipeau S (2010) Atrazine induces complete feminization and chemical castration in male African clawed frogs (Xenopus laevis). Proc Natl Acad Sci USA 107(10):4612-4617

Huang G, Li Q, Zhang X (2003) Adsorption and desorption of atrazine by three soils. Bull Environ Contam Toxicol 71:655-661

Jablonowski ND, Koeppchen S, Hofmann D, Schaeffer A, Burauel P (2008a) Spatial distribution and characterization of long-term aged C-14-labeled atrazine residues in soil. J Agric Food Chem 56(20):9548-9554. doi:10.1021/jf8017832

Jablonowski ND, Modler J, Schaeffer A, Burauel P (2008b) Bioaccessibility of environmentally aged C-14-atrazine residues in an agriculturally used soil and its particle-size aggregates. Environ Sci Technol 42(16):5904-5910. doi:10.1021/es800196z

Jablonowski ND, Köppchen S, Hofmann D, Schäffer A, Burauel P (2009) Persistence of C-14-labeled atrazine and its residues in a field lysimeter soil after 22 years. Environ Pollut 157(7):21262131. doi:10.1016/j.envpol.2009.02.004

Jablonowski ND, Hamacher G, Martinazzo R, Langen U, Köppchen S, Hofmann D, Burauel P (2010) Metabolism and persistence of atrazine in several field soils with different atrazine application histories. J Agric Food Chem 58:12869-12877. doi:10.1021/jf103577j

Jones TW, Kemp WM, Stevenson JC, Means JC (1982) Degradation of atrazine in estuarine water/sediment systems and soils. J Environ Qual 11:632-638

Jooste AM, Du Preez L, Carr JA, Giesy JP, Gross TS, Kendall RJ, Smith EE, Van Der Kraak GL, Solomon KR (2005) Gonadal development of larval male Xenopus laevis exposed to atrazine in outdoor microcosms. Environ Sci Technol 39:5255-5261

Kegley SE, Hill BR, Orme S, Choi AH (2010) PAN Pesticide Database. Pesticide Action Network, North America. http:www. pesticideinfo.org

Kloas W, Lutz I, Springer T, Krueger H, Wolf J, Holden L, Hosmer A (2009) Does atrazine influence larval development and sexual differentiation in Xenopus laevis? Toxicol Sci 107(2):376-384. doi: $10.1093 /$ toxsci/kfn232

Krutz LJ, Shaner DL, Weaver MA, Webb RMT, Zablotowicz RM, Reddy KN, Huang YB, Thomson SJ (2010) Agronomic and environmental implications of enhanced s-triazine degradation. Pest Manage Sci 66(5):461-481

Langlois VS, Carew AC, Pauli BD, Wade MG, Cooke GM, Trudeau VL (2010) Low levels of the herbicide atrazine alter sex ratios and reduce metamorphic success in Rana pipiens tadpoles raised in outdoor mesocosms. Environ Health Perspect 118(4):552-557. doi:ehp/ehp.0901418

LAWA (2003) Bericht zur Grundwasserbeschaffenheit - Pflanzenschutzmittel. Länderarbeitsgemeinschaft Wasser (LAWA) Unterausschuss Pflanzenschutzmittel im Grundwasser
Lenkowski JR, McLaughlin KA (2010) Acute atrazine exposure disrupts matrix metalloproteinases and retinoid signaling during organ morphogenesis in Xenopus laevis. J Appl Toxicol 30 (6):582-589. doi:10.1002/jat.1529

Lerch RN, Blanchard PE, Thurman EM (1998) Contribution of hydroxylated atrazine degradation products to the total atrazine load in midwestern streams. Environ Sci Technol 32(1):40-48

Loos R, Locoro G, Comero S, Contini S, Schwesig D, Werres F, Balsaa P, Gans O, Weiss S, Blaha L, Bolchi M, Gawlik BM (2010) Pan-European survey on the occurrence of selected polar organic persistent pollutants in ground water. Water Res 44 (14):4115-4126. doi:10.1016/j.watres.2010.05.032

Martinazzo R, Jablonowski ND, Hamacher G, Dick DP, Burauel P (2010) Accelerated degradation of C-14-atrazine in Brazilian soils from different regions. J Agric Food Chem 58(13):78647870. doi:10.1021/jf100549d

Olivier HM, Moon BR (2010) The effects of atrazine on spotted salamander embryos and their symbiotic alga. Ecotoxicology 19 (4):654-661. doi:10.1007/s10646-009-0437-8

Pignatello JJ, Ferrandino FJ, Huang LQ (1993) Elution of aged and freshly added herbicides from a soil. Environ Sci Technol 27:1563-1571

Renner R (2008) Atrazine effects in Xenopus aren't reproducible. Environ Sci Technol 42(10):3491-3493

Rohr JR, McCoy KA (2010) A qualitative meta-analysis reveals consistent effects of atrazine on freshwater fish and amphibians. Environ Health Perspect 118(1):20-32. doi:10.1289/ehp.0901164

Sanusi A, Millet M, Mirabel P, Wortham H (2000) Comparison of atmospheric pesticide concentrations measured at three sampling sites: local, regional and long-range transport. Sci Total Environ 263:263-277

Solomon KR, Carr JA, Du Preez LH, Giesy JP, Kendall RJ, Smith EE, Van Der Kraak GJ (2008) Effects of atrazine on fish, amphibians, and aquatic reptiles: a critical review. Crit Rev In Toxicol 38 (9): $721-772$

Spolyarich N, Hyne R, Wilson S, Palmer C, Byrne M (2010) Growth, development and sex ratios of Spotted Marsh Frog (Limnodynastes tasmaniensis) larvae exposed to atrazine and a herbicide mixture. Chemosphere 78(7):807-813. doi:10.1016/j.chemosphere.2009.11.048

Steeger T, Frankenberry M, Eisenhauer L, Tietge J (2007) White paper on the potential for atrazine to affect amphibian gonadal development. Office of Prevention, Pesticides, and Toxic Substances, Office of Pesticide Programs, Environmental Fate and Effects Division, Washington

Tavera-Mendoza L, Ruby S, Brousseau P, Fournier M, Cyr D, Marcogliese D (2002) Response of the amphibian tadpole Xenopus laevis to atrazine during sexual differentiation of the ovary. Environ Toxicol Chem 21:1264-1267

Tillitt DE, Papoulias DM, Whyte JJ, Richter CA (2010) Atrazine reduces reproduction in fathead minnow (Pimephales promelas). Aquat Toxicol 99(2):149-159. doi:10.1016/j.aquatox.2010.04.011

Tran DQ, Kow KY, McLachlan JA, Arnold SF (1996) The inhibition of estrogen receptor-mediated responses by chloro-S-triazinederived compounds is dependent on estradiol concentration in yeast. Biochem Biophys Res Commun 227(1):140-146

Trentacoste SV, Friedmann AS, Youker RT, Breckenridge CB, Zirkin BR (2001) Atrazine effects on testosterone levels and androgendependent reproductive organs in peripubertal male rats. J Androl 22:142-148

USEPA (1990) National Pesticide Survey: Summary Results of EPA's National Survey of Pesticides in Drinking Water Wells. USEPA

USEPA (2006) Decision Documents for Atrazine. U.S. Environmental Protection Agency 